Padjadjaran Nursing Journal (Jurnal Keperawatan Padjadjaran)

ISSN 2338-5324 (print)

ISSN 2442-7276 (online)

Online di http://jkp.fkep.unpad.ac.id

DOI : $10.24198 / \mathrm{jkp}$

\title{
Factors Affecting Low Back Pain among ICU Nurses
}

\author{
Dadang Rochman, Henny Suzana Mediani, Aan Nur'aeni \\ Faculty of Nursing, Universitas Padjadjaran \\ Email:hennymediani@gmail.com
}

Submitted: 28-07-2017 Accepted: 29-12-2018 Published: 01-01-2019

\begin{abstract}
Low back pain is a pain syndrome that is often felt in the lower back region accompanied by spreading to the legs. It is often associated with work-related musculoskeletal disorders. This condition is often experienced by the Intensive Care Unit (ICU) nurses, from mild to severe LBP, which may affect the productivity of work and physic of the nurses. Aim to analyze and explore the factors that affected the number of low back pain incidents in ICU nurses in hospitals in the Banten Province. This study used the correlational analytic method with a crosssectional approach. The study sample was 82 ICU nurses, obtained by total sampling. Data collection used the LKQ questionnaire (Low back pain Knowledge Questions) and observation sheets. Data analysis used the Chi-

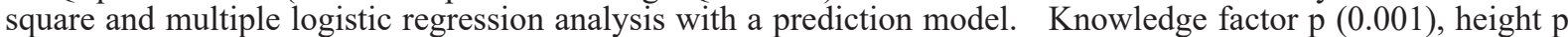
$(0.021)$, night shift frequency $\mathrm{p}(0.003)$, and weight with a $\mathrm{p}$-value $(0.021)$ had a significant relationship with low back pain, whereas the ICU space environment factor $p(0.668)$, work period $p(0.462)$, and age $p(0.079)$ did not have a significant relationship with low back pain. From related factors, knowledge had the most significant relationship with low back pain incident $(\mathrm{OR}=38.62)$. This study has significantly proven that knowledge, height, weight, and frequency of night shifts affected the low back pain in ICU nurses. The nurse's knowledge factor is the most influential factor of low back pain incident in ICU nurses. Increasing the ICU nurse's knowledge about body biomechanics by following training and developing standard operating procedures. It is suggested to reduce the amount of excessive night shift burden ICU nurses, select and setting criteria for nurses working in the ICU.
\end{abstract}

Keywords: ICU, low back pain, musculoskeletal disorder, nurses . 
Dadang Rohman : Factors Affecting Low Back Pain among ICU Nurses

\section{Introduction}

Low back pain is a pain syndrome that occurs in the lower back area and is known as a workrelated musculoskeletal disorder due to work (Meliala, 2005; Putri, 2014). The results of a previous study conducted by June and Cho (2010) in Korea, using a cross-sectional study of 1,463 ICU nurses in 22 hospitals, showeds that $90.3 \%$ of nurses experience low back pain (with results $21.9 \%$ always, $40.7 \%$ once a week, and 27.7 once a month); $18.3 \%$ of nurses have to undergo treatment therapies.

In Indonesia, the low back pain incident among ICU nurses is increasing. However, researchers have not yet determined the definitive data on the number of low back pain incidents in ICU nurses that occur nationally. Data are still limited in each region of the research location. A previous study conducted by Panjaitan (2004) at the Materna Hospital in Medan from February to May 2004 with a sample of 20 ICU nurses used action research, found that 11 nurses $(55 \%)$ have moderate low back pain, 9 nurses $(45 \%)$ experienced mild low back pain, and none experienced severe back pain.

Based on preliminary study data conducted at Banten Regional Hospitals including the Cilegon Regional Hospital, information was obtained that out of 16 ICU nurses; eight nurses had experienced mild back pain without having therapy or treatment while working in the ICU, four nurses had low back pain with having therapy or used a corset. While at Dr. Dradjat Prawiranegara Regional Hospital, Serang, out of 17 ICU nurses, only four nurses experienced low back pain. In the ICU of Adjidarmo General Hospital, Rangkasbitung, from 18 nurses, most of them experienced or complained of low back pain. In Pandeglang Hospital the number of ICU nurses was 14 people, seven experienced low back pain, this complaint caused some to have permission not to work. As for Banten Provincial Hospital, out of 17 ICU nurses, five people suffered from low back pain and underwent therapy. Based on the data above, it concluded that many ICU nurses had low back pain.

Low back pain has a significant impact on nurses, especially those who working in the ICU. The nurse staff is one of the hospital resources which is quite large in number and has a role that significantly determines the quality of service of a hospital. On the other hand, nurses as individuals are assets of companies that need protection against all work-related risks (Harianto, 2001).

Knowledge of good posture will free a person from spinal pain while poor posture is often the main reason for someone suffering from illness or low back pain (Nekada, 2011). The environmental factor in the ICU is a risk factor for the emergence of low back pain problems. For example, according to Bos et al. (2007), in their study in the Netherlands identified that ICU nurses complained of low back pain due to environmental ergonomics, such as the narrow size of the room, slippery floors, equipment that is difficult to reach and an environment that requires bending.

According to literature the incident of low back pain increases and reaches its peak at around 55 years of age (Sinaki, 2000; The Norwegian Back Pain Network, 2002). In general, skeletal muscle complaints begin to be felt at 25-65 years of working age (Tarwaka et al., 2004).

Previous research found indicated that low back pain incidents in ICU nurses occurred due to the lack of knowledge about the body posture, and being overweight as the burden on the weight of the joints may cause LBP (Fathoni, 2009; Kozier \& Erb, 2009; Nurhasanah, 2012). Meanwhile Nurhasanah (2012), found that out of 34 respondents identified, 20 respondents experienced low back pain with a percentage of $58.8 \%$ and 17 nurses experienced low back pain in the obese category $(85 \%)$.

According to Heuch et al. (2015), the Body Height factor has the potential to cause low back pain. Fathoni (2009) identified that height is related to the length of the body's axis as the burden of the anterior and posterior arm to lift the body's weight. While results of the statistical analysis conducted by Widiyanti (2009), showed no significant relationship between height and low back pain. Height as a risk factor for low back pain is still debated.

Few studies found that there was another factor that can trigger the problem of low back pain was too many night shifts which was related to reduced sleep time and poor 
Dadang Rohman : Factors Affecting Low Back Pain among ICU Nurses

quality of rest after evening service hours (Abedini, 2014; Mueke, 2005).

According to June and Cho (2010), the work period is also one of the factors that influence ICU nurses to experience low back pain. The 2-4 year working period is most at risk of experiencing low back pain. Working period fo more than five years tend to reduce the risk of LBP due to the nurse has already had more working experience in applying biomechanical techniques to the activities.

Based on the information above, the incidence of low back pain in nurses, especially those working in the ICU, is quite high. The impact on nursing services for patients in the ICU with nurses who experience low back pain is significant. There are no previous studies examine the factors that affect the number of low back pain incidents among the ICU nurses so that further research is needed.

The purpose of this study was to explore the factors that affect the low back pain incident among nurses at the hospital's Intensive Care Unit in the Banten Province.

\section{Method}

This study design used the descriptive correlational analytic method with a crosssectional approach. The population used in this study was all ICU nurses from 5 regional hospitals in the Banten Province totaling 82 nurses. The sampling technique used in this study was total sampling because the population was less than 100 . The inclusion criteria were ICU nurses who were willing to become respondents.

In this study, the instrument used in data collection to assess nurses' knowledge was the LKQ questionnaire (Low back pain Knowledge Questions) developed by Maciel et al. (2009), consisting of 16 questions and was back-translated by experts from the Faculty of Culture Universitas Padjadjaran. Also, observations were carried out for data collection on ICU environment variables using observation sheets by comparing ICU Standards guided by the Directorate General of Medical Support Services and Health Facilities Ministry of Health (2012). The face and content validity of the LKQ instrument was carried out as well as the internal consistency of the LKQ instrument assessed using Cronbach's alpha coefficient. The level of significance for the statistical test was set at 5 percent or $p<0.05$ (Maciel, 2009). The measurement of low back pain incident used a structured instrument, a development result of the researcher which contained one question about complaints of discomfort, pain in the lower back due to work performed by nurses in the ICU. The observations were stated as " $0=$ LBP", and " $1=$ not LBP" with a nominal measurement scale.

Data analysis to see the correlations used the Chi-square and to determine the dominant independent variable used the multiple logistic regression analysis with prediction models. Before the implementation, this study obtained approval from the Ethics Committee of Padjadjaran University.

\section{Result}

Univariate analysis, table 1 showed data from 82 nurses who worked in the ICU in the Banten Province Hospitals and found that 74 which was almost all nurses experienced $(90.2 \%)$ low back pain incidence, and $8(9.8$

Table 1 Frequency Distribution of Low Back Pain Incident in ICU Nurses at Regional Hospitals in Banten Province in 2017

\begin{tabular}{lcc}
\hline \multicolumn{1}{c}{$\begin{array}{c}\text { Incident of } \\
\text { Low back pain }\end{array}$} & $\mathbf{N}$ & $\mathbf{( N = 8 2 )}$ \\
\cline { 2 - 3 } & 74 & \% \\
\hline Low back pain & 8 & $90.2 \%$ \\
Not Low back pain & 82 & $9.8 \%$ \\
Total & & $100 \%$ \\
\hline
\end{tabular}


Dadang Rohman : Factors Affecting Low Back Pain among ICU Nurses

\%) did not experience low back pain.

Bivariate analysis, table 2 illustrated the results of the distribution of the Frequency of Relationship between the factors that affected the Low back pain incident in ICU nurses at regional hospitals in the Banten Province in 2017.

Table 2 showed the low back pain incident was most seen from the respondents' lack of knowledge, height more than $163 \mathrm{~cm}$, the frequency of night shifts was six times or more in a month, and overweight. The results of statistical tests indicated a significant relationship with p-value $<0.05$.

The Low back pain incident seen from the ICU environment, work period and age had a p-value $>0.05$. So there was no significant relationship between the incident of low back pain with the ICU's environment, work period, and age.

Multivariate Analysis

Table 2 Frequency Distribution Relationships between Factors that Affected the Low Back Pain Incident in ICU Nurses at Regional Hospitals in the Banten Province in 2017

\begin{tabular}{|c|c|c|c|c|}
\hline \multirow{2}{*}{$\begin{array}{c}\text { Factors that Influence } \\
\text { Low Back Pain } \\
\text { Incident }\end{array}$} & \multirow[t]{2}{*}{ N (\%) } & \multicolumn{2}{|c|}{ Incident Low Back Pain } & \multirow[t]{2}{*}{ p value } \\
\hline & & LBP & Not LBP & \\
\hline \multicolumn{5}{|l|}{ Knowledge } \\
\hline Less Knowledge & $76(92.7 \%)$ & $94.7 \%$ & $5.3 \%$ & 0.001 \\
\hline Good Knowledge & $6(7.3 \%)$ & $33.3 \%$ & $66.7 \%$ & \\
\hline \multicolumn{5}{|l|}{ ICU Room Environment } \\
\hline Not According to Standard & $65(79.3 \%)$ & $90.8 \%$ & $9.2 \%$ & 0.668 \\
\hline According to Standard & $17(20.7 \%)$ & $88.2 \%$ & $11.8 \%$ & \\
\hline \multicolumn{5}{|l|}{ Height } \\
\hline$<163 \mathrm{~cm}$ & $29(35.4 \%)$ & $79.3 \%$ & $20.7 \%$ & 0.021 \\
\hline$>163 \mathrm{~cm}$ & $53(64.4 \%)$ & $96.2 \%$ & $3.8 \%$ & \\
\hline \multicolumn{5}{|l|}{ Frequency of Night Shifts } \\
\hline$<6$ Times/Month & $14(17.1 \%)$ & $64.3 \%$ & $35.7 \%$ & 0.003 \\
\hline$\geq 6$ Times/Month & $68(82.9 \%)$ & $95.6 \%$ & $4.4 \%$ & \\
\hline \multicolumn{5}{|l|}{ Work period } \\
\hline$<5$ Years & $44(53.7 \%)$ & $93,2 \%$ & $6,8 \%$ & 0.462 \\
\hline$>5$ Years & $38(46.3 \%)$ & $86,8 \%$ & $13,2 \%$ & \\
\hline \multicolumn{5}{|l|}{ Age } \\
\hline$<35$ Years & $63(76.8 \%)$ & $93.7 \%$ & $6.3 \%$ & 0.079 \\
\hline$>35$ Years & $19(23.2 \%)$ & $78.9 \%$ & $21.1 \%$ & \\
\hline \multicolumn{5}{|l|}{ Weight } \\
\hline Obese & $53(64.6 \%)$ & $96.2 \%$ & $3.8 \%$ & 0.021 \\
\hline Not Obese & $29(35.4 \%)$ & $79.3 \%$ & $20.7 \%$ & \\
\hline
\end{tabular}

Table 3 Frequency Distribution Results of Bivariate Selection Analysis on Variables that Influence Low Back Pain Incident in ICU Nurses at Regional Hospitals in The Banten Province in 2017

\section{Variable}

Knowledge

Height

Frequency of Night Shifts

Weight

\section{p value}

0.000

0.016

0.002

0.016 
Dadang Rohman : Factors Affecting Low Back Pain among ICU Nurses

Table 4 Frequency Distribution of Multivariate Model Analysis Results on Variable of Factors Affecting Low Back Pain Incident in ICU Nurses at Regional Hospitals in the Banten Province in 2017

\begin{tabular}{lccc}
\hline \multicolumn{1}{c}{ Variable } & OR Value (Exp B) & \multicolumn{2}{c}{ C Interval } \\
\cline { 3 - 4 } & & Lower & Upper \\
\hline Knowledge & 38.62 & 2.29 & 651.7 \\
Weight & 7.09 & 0.751 & 67.105 \\
Night Shift & 6.77 & 0.787 & 58.327 \\
Height & 0.10 & 0.01 & 1.09 \\
\hline
\end{tabular}

Bivariate Selection Analysis, table 3 showed the bivariate selection results for the variables of Knowledge, Height, Frequency of Night Shifts, and Weight had a p-value $<0.25$, so a multivariate analysis could be performed on these variables.

2) Multivariate Modeling Analysis

Table 4 illustrated that from the multivariate analysis it turned out that the knowledge variable had the most significant relationship with the incident of low back pain. While the variables of weight, night shift frequency and height were confounding variables. The results of the analysis found that Odds Ratio (OR) of the knowledge variable was 38.62.

\section{Discussion}

The results of the univariate analysis in this study showed a picture of the high incident of low back pain in ICU nurses at regional hospitals in the Banten Province with a percentage of $90.2 \%$. The results of this study identified that nurses working in the ICU room experienced a lot of low back pain due to several factors such as knowledge, age, ICU space environment, height, weight, night shift, and working period. This statement is in accordance with the study results from June and Cho (2010) in Korea, who conducted a cross-sectional study from August to October 2007 with a total sample of 1,463 ICU nurses as respondents in 22 hospitals, where 1,365 respondents (93\%) filled out questionnaires, and it found that $90.3 \%$ experienced low back pain.

According to Iglarsh et al. (2003), low back pain complaints are usually felt by ICU nurses if they are handling tasks such as lifting and transferring of objects that are irregular in shape and moveable (e.g., patients), and are aggravated by the increasing frequency of work and time. This shows that low back pain experienced by ICU nurses is not due to accidents at work, but due to the demands of daily work, which aggravates the static burden on the back muscles, causing pain in the lower back or low back pain.

Bivariate, Relationships between Knowledge Level and Low Back Pain Incident in Intensive Care Unit Nurses at Regional Hospitals in the Banten province

The bivariate analysis results in this study found that there was a significant relationship between the level of nurses' knowledge of low back pain and the low back pain incident in ICU nurses; this was indicated by the value of $p=0.001(p<0.05)$. Based on the respondent distribution, most of the respondents were those with less knowledge, they experienced low back pain. Result of this current study is in accordance with the study results of previous research conducted in Turkey which has showed there was a significant relationship between knowledge and low back pain incident with $\mathrm{F}=94.271$, $(\mathrm{p}<0.05)$ (Karahan \& Bayraktar, 2013). This is in line with other study conducted by Sebastian (2013) in India, who concluded that nurses need to be given knowledge of body mechanics to prevent low back pain in nurses.

In this current study the researchers revealed that ICU nurses respondents in the Banten Province mostly lacked knowledge about low back pain $(92.7 \%)$, causing nurses working without paying attention to the proper posture following the principles of body mechanics. This was identified by the number of nurses who lacked knowledge, and experienced low back pain was as many as $94.7 \%$. 
Dadang Rohman : Factors Affecting Low Back Pain among ICU Nurses

The absence of an education or training program on biomechanical principles in work was identified in several regional hospitals in the Banten Province. For this reason, an education or training program on biomechanical principles in practice and procedures for mobilizing patients needs to be implemented in the ICU room. According to Schneider, Peterson, McGlothlin, and Blue (2004) that, training for nurses on how to treat patients well using biomechanical techniques is very important to prevent low back pain in nurses.

Relationships between Nurses' Age and Low Back Pain Incident in ICU Nurses at Regional Hospitals in the Banten Province, statistical tests of this current study identified that between low back pain incidences and age of the respondents showed no significant relationship with the value of $p=0.075$. Based on the respondent distribution, most of the respondents who were aged $<35$ years experienced low back pain compared to respondents who were aged $\geq 35$ years. This statement is in line with a cross-sectional study in Nigeria conducted by Tinubu et al. (2010), which shows the relationship between low back pain and the age factor of nurses obtains the highest result in the age group 31-40 years $(68.4 \%)$, and the lowest was in the age group above 50 years $(37.5 \%)$. Since age is a confounding factor during the work period, this factor must be adjusted to determine the relationship with the job.

The low rates of low back pain in senior nurses that are related to age and clinical practice experiences are usually due to having structural tasks and handling fewer patients (Tinubu, 2010). Another explanation is that senior nurses have better knowledge and experience about how to prevent and overcome work problems related to physical burden compared to those who are younger. (Arrighi et al., 1994).

The findings at regional hospitals in the Banten Province revealed that many ICU nurses under the age of 35 had low back pain because they were the executing nurses who directly handled patients $(93.7 \%)$. The workload of the executing nurse can cause a worker to suffer or get a work-related disorder so that this will have an impact on the health of a nurse, one of them is low back pain. (Sumanggando, 2017).

Based on the identification of this study, further research is needed regarding the ideal age factor for ICU nurses.

Relationships between ICU Room Environment and Low Back Pain Incident in Intensive Care Unit Nurses at Regional Hospitals in the Banten Province, from the results of the analysis of the relationship between the two variables above, it could be concluded that there was no significant relationship between the ICU environment and low back pain incident. Based on the distribution, most of the ICU environment which was not in accordance with the standard gave a low back pain rate. Likewise, the ICU environment that conformed to the standards contributed considerably to lower back pain.

The Directorate of Medical Support Services and Health Facilities of the Indonesian Ministry of Health (2012), has set a standard for the ICU room. The ICU room must be designed to support all essential care functions, the floor area used for each patient's bed can accommodate the space needs of all equipment and the staff who are related to patients for treatment needs.

The findings in regional hospitals in the Banten Province showed that of five hospitals, only one hospital met the standards. However, all of these five hospitals contributed to the low back pain incident. Four hospitals that did not meet the standards would run the risk of causing danger of low back pain. Hospitals with ICU rooms that already met the standards could still cause low back pain problems because the attitudes and behavior of nurses who worked were not in accordance with proper biomechanics.

Based on the results of this study, environmental factors played an important role in creating a risk of low back pain. The existence of technological advancements, increasingly advanced knowledge, and sufficient funds allocation, apparently the ICU environmental factors needed to consider safety factors.

Relationships between Height and Low Back Pain Incident in Intensive Care Unit Nurses at Regional Hospitals in the Banten Province, from the results of the analysis of the relationship between the two variables above, it could be concluded that there was a 
Dadang Rohman : Factors Affecting Low Back Pain among ICU Nurses

significant relationship between nurse height and the incidence of low back pain. Seen from the respondent distribution, this is in line with the results of a research conducted by Kurniawidjaja (2014), who found there was a significant relationship of the back arch with the level of LBP risk $(p=0.024)$. Further analysis also proved that the curvature of the back was more than or equal to $60^{\circ}$ had 11 times more chance to increase the ergonomic risk when compared with the back arch angle which was less than $60^{\circ}$.

The study results in regional hospitals in the Banten Province showed the characteristics of ICU nurses were that their height was more than $163 \mathrm{~cm}$, and in working tended to impose situations that pose a risk of low back pain without using assistive devices.

Based on the identification results of this study, the height factors can be included in the selection process for ICU nurses by considering the body weight. The ideal height for ICU nurses needs further studies.

Relationships between Weight and Low Back Pain Incident in Intensive Care Unit Nurses at Hospitals in the Banten Province, the statistical tests results between the two variables above showed there was a significant relationship. Based on the respondent distribution, most respondents who had obese weight experienced low back pain. This statement was in accordance with the results of Nurhasanah's study (2012), regarding the relationship between body weight and the low back pain incident ( $\mathrm{p}=$ 0.001 ).

Body weight contributed to the risk of low back pain since excessive weight could provide excessive burdens for joints and also affected the shift of the center of gravity which tended towards the front, causing fatigue and low back pain (Van Dieen, 1997). Based on the study in regional hospitals in the Banten Province, it was identified that many nurses with obesity experienced low back pain. The absence of provisions or limits on weight for nurses working in the ICU could be seen in the tendency of nurses with excess weight to work in the ICU. The monotonous daily work routine and poor lifestyles tend to obesity. Obesity in ICU nurses makes it difficult to make movements in work, and with a heavy workload in the ICU, it will worsen the risk of low back pain. It should be considered that obese nurses do not work in the ICU room.

Relationships between Frequency of the Nurse Night Shift and Low Back Pain Incident in Intensive Care Unit Nurses in Hospitals in the Banten Province, the statistical tests results between the two variables above showed was identified a significant relationship. Based on the respondents' distribution, most of the respondents had a shift frequency of 6 times a night or more in a month experienced low back pain. This statement is in accordance with the results of a study conducted by June and Cho (2010) in Korea, stating that there is an influence between the frequency of night shifts and the incident of low back pain ( $\mathrm{p}=$ 0.018). Nurses who get night shifts more than six times a month have a higher risk of low back pain compared to those who work less than six times a month (June \& Cho, 2010).

Garland (2012); Heffner et al. (2011); Mertens et al. (2015); and Roehrs et al. (2012), identified that reduced sleep time and poor quality of rest due to excessive night shifts can affect autonomy, neuroendocrine and neuroimmunological systems that can stimulate the inflammatory response, slow down the process of restoring damaged tissues and increase pain sensitivity.

The researcher identified that nurses in the ICU in the regional hospitals in Banten Province had a high frequency of night shifts with high rates of low back pain, there were even some ICU nurses who were night shift' specialists or only worked on consecutive night shifts, especially unmarried nurses.

Based on the results of this study, it was necessary to review the distribution of night shift schedules for ICU nurses to be more evenly distributed, and preferably in one month less than five times of night shifts. The addition of the number of ICU nurses might be a solution to reduce the amount of excessive night shift burden.

Relationships between the Nurse's Length of Employment and Low Back Pain Incident in Intensive Care Unit Nurses at Hospitals in the Banten Province, based on the respondents' distribution, most of the majority of respondents who had a work period of fewer than five years experienced low back pain. The statistical tests results 
Dadang Rohman : Factors Affecting Low Back Pain among ICU Nurses

between the two variables above showed no significant relationship $(\mathrm{p}=0.462)$. This finding is in accordance with the study results by Meliyanti (2012), regarding the relationship between tenure and low back pain disorder which was not significant with $\mathrm{p}=0.258$.

Monotonous physical work carried out for a long time without work rotation can cause fatigue, which can increase the risk of skeletal muscle injury, one of which is in the lower back of the worker (Meliyanti, 2012).

A work period of less than or equal to 5 years has a high rate of low back pain, due to lack of experience and as an executing nurse obviously, the workload is quite high.

The ICU nurse's work period did not have a meaningful relationship. However, this factor contributed to the incident of low back pain in ICU nurses. Therefore, as one of the considerations for ICU nurses, it was necessary for the hospital institution to apply a rotation system of fewer than five years.

Multivariate, based on the respondents' distribution, the knowledge variable had the most significant relationship. The results of the analysis found that Odds Ratio (OR) of the knowledge variable was 38.62. It means that respondents who had poor knowledge about low back pain would be at risk of suffering low back pain by 38 times higher than respondents who had good knowledge about low back pain after being controlled by the variables of weight, night shift frequency, and height.

Geller (2001) reveals that knowledge or cognitive is a fundamental domain in shaping one's actions. Before a worker adopts a new behavior, he/she must first know what the meaning or benefits of the behavior are for $\mathrm{him} / \mathrm{her}$. So that a worker will implement safe behavior if he/she already know the purpose and benefits for his/her security and what dangers will occur if he/she does not implement it (Annishia, 2011).

From this currente study results, it expected that there should be an increase knowledge of biomechanics for ICU nurses by routinely conducting training, or in-service educational programs, health promotion in the form of posters and posters in the ICU. The selection process opened up more significant opportunities in the proportion of higher levels of nurse education. The development of Evident Base Practice in the field of nursing needed to be improved. Further research is needed for ICU nurses in the hospital environment required to be developed so that it could explore knowledge about other factors associated with low back pain among ICU nurses.

\section{Conclusion}

From the study results can be concluded that the majority of nurses working in the ICU room of regional hospitals in the Banten Province have experienced low back pain. Several factors in this study proved to have a significant relationship to the incident of low back pain, namely knowledge factor, night shift, height and, weight. While other factors based on study results such as the ICU environment, work period, and age do not have a significant relationship with the incident of low back pain in ICU nurses, but these three variables are substantially important variables related to the low back pain incident. Of the three factors associated with the low back pain incident in ICU nurses, the knowledge factor is the most influential factor because knowledge is a fundamental basis in forming a person's behavior. A worker will apply safe conduct if they already know the purpose and benefits of their security and what danger will occur if they do not implement it.

\section{References}

Abedini, S., Morowatisharifabad, M.A., Enjezab, B., Barkhordari, A., \& Fallahzadeh, H. (2014). Risk perception of nonspecific low back pain among nurses: A qualitative approach. Health Promot Perspect, 4(2), 221-229.

Annishia, F.B. (2010). Analisis perilaku tidak aman pekerja konstruksi PT. PP (Persero) di Proyek Pembangunan Tiffany Apartemen Jakarta Selatan tahun 2011. Skripsi. FKIK UIN.

Arrighi, H.M., \& Hertz-Picciotto, I. (1994). The evolving concept of the healthy worker 
Dadang Rohman : Factors Affecting Low Back Pain among ICU Nurses

survivor effect. Epidemiology, 5, 189-196.

Bos, E., Krol, B., van der Star, L., \& Groothoff, J. (2007). Risk factors and musculoskeletal complaints in non-specialized nurses, ICU nurses, operation room nurses, and X-ray technologists. International Archives of Occupational and Environmental Health, 80, 198-206.

Direktorat Bina Pelayanan Penunjang Medik dan Sarana Kesehatan Direktorat Bina Upaya Kesehatan. (2012). Pedoman teknis bangunan rumah sakit ruang perawatan intensif. Available at aspak.buk.depkes. go.id/.../5., Retrieved May,17, 2016.

Fathoni, H., Handoyo., \& Keksi, G.S. (2009). Hubungan sikap dan posisi kerja dengan low back pain pada perawat di RSUD Purbalingga. Jurnal Keperawatan Soedirman (The Soedirman Journal of Nursing), 4(3), 131- 139.

Garland, E.L. (2012). Pain processing in the human nervous system: A selective review of nociceptive and biobehavioral pathways. Prim Care, 39, 561-571.

Geller, E.S. (2001). The psychology of safety handbook. USA: Lewis Publisher.

Harianto, D.S. (2001). Tinjauan tingkat risiko low back pain (LBP) pada elemen kerja keperawatan bagian ICU-A Rumah Sakit Pusat Pertamina (RSPP) Jakarta. Available at http://lib.ui.ac.id/opac/themes/libri2/detail. jsp?id=71337.

Heffner, K.L., France, C.R., Trost, Z., Ng, H.M., \& Pigeon, W.R. (2011). Chronic low back pain, sleep disturbance, and interleukin-6. Clin J Pain, 27, 35-41.

Heuch, I., Hagen, K., \& Zwart, J.A. (2015). A comparison of anthropometric measures for assessing the association between body size and risk of chronic low back pain: The HUNT study. PLoS ONE, 10(10), e0141268. doi:10.1371/ journal.pone.0141268.

Iglarsh, A., Kendal, F. Lewis, C., \& Sharman, S. (2003). Posture. American Physical
Therapy Association.

June, K.J., \& Cho, S.H. (2010). Low back pain and work-related factors among nurses in intensive care units. Journal of Clinical Nursing, 20, 479-487.

Karahan, A., \& Bayraktar, N. (2013). Effectiveness of an education program to prevent nurses' low back pain: An interventional study in Turkey. Workplace health \& safety, 61(2).

Kozier \& Erb (2009). Audrey berman techniques in clinical nursing. Alih bahasa Eny Meiliya et al. Buku ajar praktik keperawtan klinis (Edisi 5). Jakarta: EGC.

Kurniawidjaja, L.M. (2014). Pengendalian risiko ergonomi kasus low back pain pada perawat di rumah sakit. Pusat Kajian dan Terapan Keselamatan dan Kesehatan Kerja, Fakultas Kesehatan Masyarakat, Universitas Indonesia.

Meliala, L., \& Pinzon, R. (2005). Breaththrough in management of acute pain, dalam Mahana J., et al. Naskah Lengkap Pertemuan Ilmiah Nasional I Kelompok Studi Nyeri Perdossi, Manado, 142-153.

Meliyanti, C. (2012). Hubungan sikap tubuh dan shift kerja dengan gangguan otot punggung bawah (low back pain) terhadap pekerja bagian produksi kelapa sawit (PKS). Luwu I PTPN XIV. Burau.

Mertens, P., Blond, S., David, R., \& Rigoard, P. (2015). Anatomy, physiology and neurobiology of the nociception: A focus on low back pain (Part A). Neurochirurgie, 61, S22-S34.

Muecke, S. (2005). Effects of rotating night shifts: Literature review. Journal of Advanced Nursing, 50, 433-439.

Nekada, C.D.Y. (2011). Correlation between knowledge levels on body postures and spinal pain incidences in nursing students of Respati Yogyakarta University. Journal Respati. Available at respati.ac.id/index.php/ ilmukeperawatan/article/.../202. 
Dadang Rohman : Factors Affecting Low Back Pain among ICU Nurses

Nurhasanah, S. (2012). Analisis hubungan obesitas sentral dengan kejadian nyeri pinggang bawah pada pasien di Poli Fisioterapi Rumah Sakit Universitas Hasanudin Makasar.

Panjaitan, N. (2004). Upaya pencegahan terjadinya low back pain pada perawat di Instalasi Perawatan Intensif Rumah Sakit Materna Medan. USU Repository C 2008.

Putri, A.S., Saftarina, F., \& Wintoko, R. (2014). Hubungan masa kerja dan posisi kerja dengan kejadian low back pain (LBP) pada pekerja pembersih kulit bawang di Unit Dagang (UD) Bawang Lanang Kelurahan Iringmulyo Kota Metro. Jurnal kedokteran Unila Lampung.

Roehrs, T.A., Harris, E., Randall, S., \& Roth, T. (2012). Pain sensitivity and recovery from mild chronic sleep loss. Sleep, 35, 16671672.

Schneider, S., Peterson, E.L., McGlothlin, J.D., \& Blue, C. (2004). The developments of an ergonomics training program to identify, evaluate and control musculoskeletal disorders among nursing assistants at a staterun veterans' home. Journal of Occupational and Environmental Hygiene, 1(1), D10-D16. doi:10.1080/15459620490264427.

Sebastian, S. (2013). Observational study of body mechanics of selected nursing procedures among staff nurses with and without backpain. International Journal of Nursing Education, 5(2).
Sinaki M., \& Mokri, B. (2000). Low back pain and disorders of lumbar spine. In: Braddom, Ed. Physical medicine and rehabilitation. Philadelphia: W.B Saunders Company, 85393.

Sumanggando, M. (2017). Hubungan beban kerja perawat dengan kejadian low back pain (LBP) pada Perawat Pelaksana di RS Tk. III R.W. Monginsidi Manado. eJurnal Keperawatan (e-Kp), 5 .

Tarwaka et al. (2004). Ergonomi untuk keselamatan kesehatan kerja dan produktivitas. Surakarta: UNIBA Press.

The Norwegian Back Pain Network. (2002). Acute low back pain - Interdisciplinary clinical guidelines. Oslo. The Norwegian Back Pain Network.

Tinubu, B.M., Chidozie, E., Mbada, C.E., Adewale, L., Oyeyemi, A.L., \& Fabunmi, A.A. (2010). Work-related musculoskeletal disorders among nurses in Ibadan, Southwest Nigeria: A cross-sectional survey. $B M C$ Musculoskelet Disorders, 11(12).

Van Dieen, J.H. (1997). Are recruitment pattern of the trunk musculature compatible with a synergy based on the maximization of endurance?. Journal of Biomechanics, 30, 1095-1100.

Widiyanti, E.C.L., Basuki, E., \& Jannis, J. (2009). Lifting and transferring patient as risk factors for low back pain among female nurses. Maj Kedokt Indon, 59(3). 